\title{
Tomato Hybrid and Local Varieties Screened for Resistance to Bacterial Wilt Caused by Ralstonia solanacearum under Screen House and Field Conditions
}

\author{
Marie Epiphane Dossoumou1,2, Rachidatou Sikirou', Appolinaire Adandonon ${ }^{3}$, \\ Julienne Gonroudobou1, Lamine Baba-Moussa ${ }^{2}$ \\ ${ }^{1}$ Laboratoire de Défense des Cultures (LDC), Centre de Recherches Agricoles d'Agonkanmey (CRA-Agonkanmey), Institut \\ National des Recherches Agricoles du Bénin (INRAB), Cotonou, Bénin \\ ${ }^{2}$ Laboratoire de Biologie et de Typage Moléculaire en Microbiologie (LBTMM), Faculté des Sciences et Techniques, Université \\ d'Abomey-Calavi, Cotonou, Bénin \\ ${ }^{3}$ Ecole de Gestion et de Production Végétale et Semencière (EGPVS), Université Nationale d'Agriculture (UNA), Porto-Novo, \\ Bénin \\ Email: rachidatous@yahoo.fr
}

How to cite this paper: Dossoumou, M.E. Sikirou, R., Adandonon, A., Gonroudobou, J. and Baba-Moussa, L. (2021) Tomato Hybrid and Local Varieties Screened for Resistance to Bacterial Wilt Caused by Ralstonia solanacearum under Screen House and Field Conditions. American Journal of Plant Sciences, 12, 1222-1235. https://doi.org/10.4236/ajps.2021.128085

Received: July 2, 2021

Accepted: August 6, 2021

Published: August 9, 2021

Copyright (c) 2021 by author(s) and Scientific Research Publishing Inc. This work is licensed under the Creative Commons Attribution International License (CC BY 4.0)

http://creativecommons.org/licenses/by/4.0/

\begin{abstract}
Bacterial wilt is the most damaging disease of tomato in Benin. To select resistant varieties of tomato against bacterial wilt, 21 tomato varieties were evaluated twice under screen house and field conditions in a randomized complete block design with four replicates and 21 treatments which are the tested varieties. Three weeks old tomato seedlings were inoculated by crown flooding with $40 \mathrm{ml}$ of a bacterial suspension of $R$. solanacearum strain CR-1103-2, phylotype I sequvar 14. At 28 days after inoculation, the control resistant varieties Hawaii 7997 and PADMA maintained their resistance and the known susceptible variety Tohounvi showed to be susceptible to the bacterial wilt. Among the hybrid tomato varieties, only Cobra 26 was moderately resistant. No resistant line was found among the tested local varieties. The hybrid varieties Buffalo, Petomech, Tropimech, Sumo, Prado, Ninja, Jaguar, Anaya, Topaze, Cobra 34, Heinz, Kiara, Euclid and local Kêkêfô, Akikonkouin, Agbotrui and Adjaa were all susceptible. In conclusion, Cobra 26 emerges as a new variety of tomato moderately resistant to bacterial wilt. This is a new finding since it adds. All the tested varieties, regardless of their resistance, were colonized by $R$. solanacearum. This is a challenge for tomato farmers who must practice sanitation in their fields when producing tomato susceptible or resistant varieties. The variety Cobra 26 must be scaled up to farmers.
\end{abstract}




\section{Keywords}

Solanaceae Diseases, Varietal Resistance, Control Method, Lycopercicum esculentum, Benin

\section{Introduction}

Tomato (Lycopercicum esculentum) is one of the forty most cultivated vegetable species in the world. Its world production was estimated in 2019 at 180,766,329 tons [1]. In Benin, it is grown throughout the country [2], occupying an area of 37,648 ha [1] on which 274,700 tons of tomatoes are harvested [1]. Tomato is usually consumed by Beninese [3], due to its richness in vitamins and minerals that are no longer to be denied [4]. Its production occupies an important socio-economic activity in Benin [5] where the average yield is $7.29 \mathrm{t} / \mathrm{ha}$ while $35.97 \mathrm{t} / \mathrm{ha}$ is produced in the world in 2019 [1]. This low yield is mainly due to many factors including pests and diseases, particularly the bacterial wilt caused by the phytopathogenic bacterium Ralstonia solanacearum [6]. This bacterium causes yield losses of up to $72 \%$. Bacterial wilt is known as economically important and most damaging disease of solanaceous plants [7].

To control bacterial wilt for which effective bactericides do not exist [8] [9], several approaches have been developed. These approaches have involved soil disinfection [10], grafting techniques [11] [12], the use of disease-reducing plants that sanitize the soil [13] and crop rotation with non-host crops [14] [15]. Unfortunately, these different methods show limited effectiveness when not integrated. The most effective and worldwide reported management method is the use of resistant genes. According to Oussou et al. [16], disease management through the introduction of resistant varieties is the appropriate method that is less expensive for farmers and not aggressive to the environment. Thus, several resistant varieties have been selected worldwide. Wang et al. [17] developed the bacterial wilt resistant tomato variety Hawaii 7996 at the World Vegetable Center. In Korea, Kim et al. [18] selected four resistant and two moderately resistant accessions from 285 accessions tested from all continents. To detect resistant genes to be improved for rootstock, Ganiyu et al. [19] identified tomato varieties AVT09803, AVT00201, Tomachiva and Eyetom resistant to bacterial wilt. Laeshita and Arwiyanto [20], by evaluating bacterial wilt resistance of 16 tomato varieties, identified Servo, Kaliurang, Melinda, Amelia, Rewako varieties as moderately resistant. In Benin, few varieties resistant to bacterial wilt are available. Research by Oussou et al. [16], when evaluating the behaviour of nine tomato varieties to bacterial wilt, identified two varieties, PADMA and Platinum as resistant. These two resistant varieties are not sufficient, especially for good production of tomato in contaminated areas. The choice of farmers is also limited regarding organoleptic criteria. Of the 36 tomato varieties grown in Benin [21], the status of only eight of them to bacterial wilt was known. The behavior of Be- 
nin local tomato varieties has not been reported except the susceptibility of variety Tounvi [6] [7] [16]. To increase the number of tomato resistant genes, this study aims to evaluate the behavior of other hybrid and local tomato cultivated varieties in Benin.

\section{Materials and Methods}

\subsection{Tomato Varieties Tested}

Twenty-one tomato varieties comprising 16 hybrids and 5 locals were tested, namely Sumo, Prado, Ninja, Jaguar, Anaya, Topaze, Cobra 26, Cobra34, Euclide, Savana, Kiara, Buffalo, Petomech, Tropimech, PADMA and Hawaii 7997 as hybrids varieties and Kêkêkô, Tounvi, Akikonkouinkouin, Agbotrui and Adjaa as local varieties. The hybrid varieties were obtained from registered seed "Bénin semence" distributors and the local varieties were provided by the Vegetable Program of National Agricultural Research Institute of Bénin (INRAB, Benin). The variety Hawaii 7997 was obtained from the World Vegetable Center, Cotonou. The local variety Tounvi was used as the known susceptible control [6] while PADMA [16] and Hawaii 7997 [22] were considered as resistant controls.

\subsection{Inoculum Preparation}

The virulent strain CR-1103-2 of phylotype I sequvar $14^{*}$, obtained from the experimental site of World Vegetable Center, Cotonou, was used in this study. It was mass-produced on SMSA culture medium [23] from a 48-hour old isolated colony. After 48 hours of incubation at $30^{\circ} \mathrm{C}$, the bacterial cream from the mass production was removed and suspended in sterile distilled water (SDW). The obtained stock solution was adjusted using a spectrophotometer to the concentration of $10^{8}$ Colony Forming Unit per milliliter $\left(\mathrm{CFU} \cdot \mathrm{ml}^{-1}\right)$.

\subsection{Screen House Experimentation}

The experiment was conducted in the screen house of the Laboratory of Crop Protection, INRAB $\left(6^{\circ} 24^{\prime} 35^{\prime \prime} \mathrm{N}, 2^{\circ} 19^{\prime} 56^{\prime \prime} \mathrm{E}\right)$, Benin. The trial was set up using a Randomized Complete Block design with four replicates and 21 treatments that are the tomato varieties. The average air temperatures prevailing were $28.3^{\circ} \mathrm{C}$ during the first experiment conducted from April to May (rainy period) and $31.2^{\circ} \mathrm{C}$ during the second experiment conducted from August to September (dry period). The nursery was carried out for three weeks on a sterilized soil/manure substrate $(2 \mathrm{v}: 1 \mathrm{v})$ for one hour at $80^{\circ} \mathrm{C}$. The young tomato plants of three weeks were root cut with hand and then transplanted into pots containing $0.5 \mathrm{~kg}$ of sterilized soil with manure substrate. There were 10 pots per variety per block. Each tomato seedling was inoculated by crown flooding with $40 \mathrm{ml}$ of inoculum. Five plants per variety were inoculated with SDW to serve as control. The inoculated seedlings were monitored for 28 days after transplanting. Compost (10 g) was applied to each seedling 14 days after transplanting. Data were collected three times a week at 48 -hour intervals from the day of transplanting. 


\subsection{Field Experimentation}

\section{Determination of the existing bacterial concentration in the soil at the expe- rimental site}

To determine $R$. solanacearum concentration existing in soil before the experiment, rhizosphéric soils were collected three days before planting. From a composite of nine rhizospheric soil samples from each $6 \mathrm{~m}^{2} 10$ grams were suspended in $100 \mathrm{ml}$ of SDW. After stirring and decanting the mixture, $45 \mathrm{ml}$ of the supernatant was taken, adjusted to $50 \mathrm{ml}$ and centrifuged at $6000 \mathrm{rpm}$ for $5 \mathrm{mi}-$ nutes. The supernatant was discarded and the pellet suspended in $5 \mathrm{ml}$. A series of four dilutions were made from this stock solution. Plates were inoculated with $100 \mu \mathrm{l}$ per dilution and then incubated for 48 hours at $30^{\circ} \mathrm{C}$.

\subsection{Experiment Design}

On-Field trials were conducted at the INRAB Vegetable Research experimental site located at Abomey-Calavi Township. This experimental site has the $R$. solanacearum disease history and is naturally infested. The experimental design was a Randomized Complete Block design with four replicates. Tomato seedlings of three weeks old were transplanted on the field at a density of 25.000 plants per ha with $0.5 \mathrm{~m}$ between plants and $0.8 \mathrm{~m}$ between plant rows. The seedlings were watered twice a day, early in the morning and late in the afternoon, by sprinkler irrigation. Regular weeding was carried out. An organic manure based on well-decomposed poultry manure was applied to the seedlings one week after transplanting at a rate of $10 \mathrm{t} / \mathrm{ha}$ and a mineral manure composed of NPK 20 10 - 10 was applied two weeks after transplanting at a rate of $200 \mathrm{~kg} / \mathrm{ha}$. To protect plants against mite and fungus attacks, two phytosanitary treatments were carried out at three and five weeks after transplanting with the products ACARIUS 18 EC (Abamectine $18 \mathrm{~g} / \mathrm{l}, 0.75 \mathrm{l} / \mathrm{ha}$ ) and TOPSIN M 70 WP (0.5 $\mathrm{kg} / \mathrm{ha}$ ) obtained from the authorized distributor named "Accueil Paysan". The experiments were monitored for 28 days after transplanting. Data were collected three times a week at 48-hour intervals from the day of transplanting. Mean temperatures prevailing were $26.4^{\circ} \mathrm{C}$ and $32.8^{\circ} \mathrm{C}$ during the first and second experiments, respectively.

\subsection{Colonization of Tomato Plants by Ralstonia solanacearum}

The detection of bacteria in inoculated but not wilted plants was performed at 28 days after transplanting in screen house and field experiment. The fingerprinting technique described by [16] was used. Ten-cm length stems of unwilted plants were cut from the collar. Each stem was rinsed under the tap water, cleaned with $70 \%$ ethanol and then flamed with $90^{\circ}$ ethanol. The base of each stem was refreshed with a sterile scalpel to make five fingerprints per plant on the SMSA medium. Inoculated plates were incubated at $30^{\circ} \mathrm{C}$ for 48 hours.

Stem samples were also collected from inoculated and wilted plants to check and confirm presence of the bacteria as responsible for the disease symptoms 
observed after inoculation. A plant is considered colonized when $R$. solanacearum is isolated from that plant, whether it is wilted or not.

\subsection{Collected Data}

\section{Incidence of Bacterial Wilt (IBW):}

The Incidence of Bacterial Wilt (IBW) was determined by the ratio of the number of wilted plants (NWP) to the total number of inoculated plants (NIP) according to the formula:

$$
\mathrm{IBW}=(\mathrm{NWP} / \mathrm{NIP}) \times 100
$$

The classification of varieties according to their resistance based on the IBW was carried out according to the [24] scale defined in Table 1.

\section{Bacterial Colonization Index}

The bacterial colonization index (BCI) was calculated as the percentage of plants infested with $R$. solanacearum. It was determined according to the formula:

$$
\mathrm{BCI}=((\mathrm{NWP}+\mathrm{NCP}) / \mathrm{NIP}) \times 100
$$

NWP: Number of wilted plants; NCP: Number of colonized plants and NPI: Total number of inoculated plants.

\section{The area under the bacterial wilt incidence progress curve}

The area under the bacterial wilt incidence progress curve (AUIbwPC) is a function of time. AUIbwPC $=f(t)$. It was calculated according to the formula:

$$
\text { AUIbwPC }=\sum_{i=1}^{k}\left[\left(\mathrm{IBW}_{i}+\mathrm{IBW}_{i+1}\right)\left(t_{i+1}-t_{i}\right)\right] / 2
$$

bw is bacterial wilt and $t_{i}$ represents time at the period i [25].

\subsection{Statistical Analysis}

One-way analysis of variance (ANOVA) was used. It was applied to the Bacterial Colonization Index, the Bacterial Wilt Incidence and the AUIbwPC. To classify the means into a homogeneous group, the Student-Newman-Keuls test was used. The analyses were carried out under STATA statistical software.

Table 1. Resistance classification scale based on the Bacterial Wilt index.

\begin{tabular}{cc} 
Reaction & Incidence (\% wilted plants) \\
Highly resistant (HR) & $0 \%$ \\
Resistant (R) & $1 \%-10 \%$ \\
Moderately Resistant (MR) & $>10 \%-20 \%$ \\
Moderately Susceptible (MS) & $>20 \%-30 \%$ \\
Susceptible (S) & $>30 \%-70 \%$ \\
Highly Susceptible (HS) & $>70 \%$ \\
\hline
\end{tabular}


The virulent strain CR-1103-2 of phylotype I sequvar $14^{\star}$, obtained from the experimental site of World Vegetable Center, Benin in Abomey-Calavi, was used in this study. It was mass-produced on SMSA culture medium [23] from a 48-hour old isolated colony. After 48 hours of incubation at $30^{\circ} \mathrm{C}$, the bacterial cream from the mass production was removed and suspended in sterile distilled water (SDW). The obtained stock solution was adjusted using a spectrophotometer to the concentration of $10^{8}$ Colony Forming Unit per milliliter $\left(\mathrm{CFU} \cdot \mathrm{ml}^{-1}\right)$.

\section{Results}

\subsection{Behavior of Tomato Varieties after Inoculation with Ralstonia solanacearum in the Screen House}

Various responses were obtained from tomato varieties inoculated with $R$. solanacearum. This variation in response was observed in terms of bacterial wilt incidence, bacterial colonization index and area under the bacterial wilt incidence progress curve. The analyses of variance indicate a significant difference among varieties regarding IBW $(P=0.000)$ and AUIbwPC $(P=0.000)$. As for $B C I$, no significant difference $(\mathrm{P}=0.1849)$ was observed among the varieties during the two experiments.

The variety Cobra 26 showed the lowest incidence of bacterial wilt during the two experiments ( $15 \%$ and $17.5 \%$, respectively) which was not significantly different from that of the tested resistant varieties PADMA and Hawaii 7997 for which the IBW was 0\%. The Kêkêfô, Tropimèche, Petomech, Topaze, Jaguar, Prado, Tounvi, Akikonkouin, Anaya, Agbotrui, Cobra 34, Kiara, Adjaa, Savana, Buffalo, Ninja, Sumo, and Euclid varieties were all susceptible with an IBW ranging from $60.71 \%$ to $97.50 \%$. During the experiment 2, the IBW increased for $76.19 \%$ of the tested varieties (Table 2).

The colonization test showed that all the tested varieties were colonized by $R$. solanacearum including the resistant check varieties. The varieties Tropimech, Kêkêfô, Petomech and Hawaii 7997 were 100\% colonized. The bacterial colonization index increased during the experiment 2 compared to the experiment 1 for most varieties.

The area under the bacterial wilt incidence progress curve (AUIbwPC) showed a significant difference among varieties for the two experiments. The varieties Kêkêfô and Kiara showed the highest AUIbwPC, whether during the first or the experiment 2. As for the IBW and BCI, an increase in AUIbwPC was noted during the experiment 2 for $80.95 \%$ of the varieties. The increase of the IBW ranged from $4.76 \%$ to $42.5 \%$ for the susceptible varieties.

During the experiment 1, the lowest AUIbwPC (0 to 30) were recorded for the Hawaii 7997, PADMA and Cobra 26 varieties with a none significant difference (Table 2). The same trend was noted for the three varieties except the AUIbwPC of Cobra 26 was slightly higher than those of Hawaii 7997 during the experiment

2 (Table 2). The AUIbwPC was significantly high for other varieties.

In the screen house, considering the IBW, BCI and AUIbwPC of the experiment 2, the tomato varieties PADMA and Hawaii 7997 were highly resistant, the 
Table 2. Incidence of bacterial wilt, bacterial colonization index and area under the bacterial wilt incidence progress curve of 21 tomato varieties evaluated in the screen house experiment.

\begin{tabular}{|c|c|c|c|c|c|c|c|}
\hline \multirow{2}{*}{ Varieties } & \multicolumn{2}{|c|}{ IBW } & \multicolumn{2}{|c|}{ AUIbwPC } & \multicolumn{2}{|c|}{ BCI } & \multirow{2}{*}{ Reaction } \\
\hline & E1 & E2 & E1 & E2 & E1 & E2 & \\
\hline kêkêfô & $100 \pm 0 \mathrm{a}$ & $95 \pm 2.89 \mathrm{a}$ & $240 \pm 10 \mathrm{a}$ & $227.5 \pm 7.22 \mathrm{abcd}$ & $100 \pm 0 \mathrm{a}$ & $95 \pm 2.89 \mathrm{a}$ & HS \\
\hline Akikonkouin & $75 \pm 13.23 \mathrm{abcd}$ & $97.5 \pm 2.5 \mathrm{a}$ & $177.5 \pm 32.05 \mathrm{ab}$ & $236.25 \pm 5.54 \mathrm{abc}$ & $77.5 \pm 14.36 \mathrm{a}$ & $97.5 \pm 2.5 \mathrm{a}$ & HS \\
\hline PADMA & $0 \pm 0 \mathrm{e}$ & $0 \pm 0 \mathrm{c}$ & $0 \pm 0 \mathrm{~d}$ & $0 \pm 0 \mathrm{f}$ & $52.5 \pm 22.86 \mathrm{a}$ & $100 \pm 0 \mathrm{a}$ & HR \\
\hline Buffalo & $35 \pm 14.43 \mathrm{a}$ & $60.71 \pm 8.99 b$ & $83.57 \pm 35.64 \mathrm{~cd}$ & $144.64 \pm 25.48 \mathrm{de}$ & $72.5 \pm 21.36 \mathrm{a}$ & $71.43 \pm 8.25 \mathrm{a}$ & S \\
\hline Petomech & $90 \pm 7.07 \mathrm{bcd}$ & $80 \pm 5.77 \mathrm{ab}$ & $220 \pm 22.82 \mathrm{ab}$ & $207.5 \pm 16.52 \mathrm{abcd}$ & $100 \pm 25 \mathrm{a}$ & $87.5 \pm 2.5 \mathrm{a}$ & HS \\
\hline Savana & $60 \pm 0 \mathrm{abcd}$ & $87.5 \pm 9.46 \mathrm{a}$ & $142.5 \pm 4.79 \mathrm{abc}$ & $223.75 \pm 27.34 \mathrm{abcd}$ & $80 \pm 11.55 \mathrm{a}$ & $95 \pm 2.89 \mathrm{a}$ & HS \\
\hline Ninja & $45 \pm 6.45 \mathrm{abc}$ & $77.5 \pm 2.5 \mathrm{ab}$ & $105 \pm 14.86 \mathrm{abcd}$ & $178.75 \pm 11.97 \mathrm{a} d e$ & $82.5 \pm 17.5 \mathrm{a}$ & $92.5 \pm 4.79 \mathrm{a}$ & HS \\
\hline Topaze & $80 \pm 9.15 \mathrm{abcd}$ & $97.5 \pm 2.5 \mathrm{a}$ & $197.5 \pm 25.62 \mathrm{ab}$ & $223.75 \pm 11.43 \mathrm{abcd}$ & $82.5 \pm 11.09 \mathrm{a}$ & $97 . \pm 2.5 \mathrm{a}$ & HS \\
\hline Jaguar & $80 \pm 8.16 \mathrm{abcd}$ & $90 \pm 7.07 \mathrm{a}$ & $175 \pm 30.21 \mathrm{ab}$ & $237.5 \pm 29.05 \mathrm{abc}$ & $87.5 \pm 9.46 \mathrm{a}$ & $92.5 \pm 7.5 \mathrm{a}$ & HS \\
\hline Sumo & $45 \pm 16.58 \mathrm{abc}$ & $87.5 \pm 4.79 \mathrm{a}$ & $117.5 \pm 35.50 \mathrm{abcd}$ & $216.25 \pm 16.75 \mathrm{abcd}$ & $60 \pm 18.71 \mathrm{a}$ & $92.5 \pm 4.79 \mathrm{a}$ & HS \\
\hline Prado & $80 \pm 8.16 \mathrm{abcd}$ & $90 \pm 5.77 \mathrm{a}$ & $180 \pm 24.15 \mathrm{ab}$ & $230 \pm 22.73 \mathrm{abcd}$ & $95 \pm 5 \mathrm{a}$ & $92.5 \pm 4.79 \mathrm{a}$ & HS \\
\hline Tounvi & $80 \pm 14.14 \mathrm{abcd}$ & $95 \pm 5 \mathrm{a}$ & $185 \pm 39.26 \mathrm{ab}$ & $260 \pm 27.08 \mathrm{abc}$ & $80 \pm 14.14 \mathrm{a}$ & $95 \pm 5 \mathrm{a}$ & HS \\
\hline Cobra26 & $15 \pm 6.45$ ef & $17.5 \pm 8.54 \mathrm{~d}$ & $30 \pm 13.39 \mathrm{~cd}$ & $36.25 \pm 20.75 \mathrm{e}$ & $60 \pm 24.49 \mathrm{a}$ & $95 \pm 5 \mathrm{a}$ & MR \\
\hline Anaya & $42.5 \pm 11.81 \mathrm{ab}$ & $75 \pm 6.45 \mathrm{ab}$ & $177.92 \pm 38.21 \mathrm{ab}$ & $183.75 \pm 21.35 \mathrm{ab}$ & $91.67 \pm 4.81 \mathrm{a}$ & $92.5 \pm 4.79 \mathrm{a}$ & HS \\
\hline Cobra34 & $66.67 \pm 13.60 \mathrm{abcd}$ & $71.43 \pm 5.31 \mathrm{ab}$ & $83.75 \pm 23.57 \mathrm{a} \mathrm{cd}$ & $180 \pm 18.60 \mathrm{a}$ & $85 \pm 8.66 \mathrm{a}$ & $97.5 \pm 2.5 \mathrm{a}$ & HS \\
\hline Kiara & $68.75 \pm 11.97 \mathrm{abcd}$ & $95 \pm 2.89 \mathrm{a}$ & $141.07 \pm 26.48 \mathrm{abc}$ & $276.78 \pm 17.59 c$ & $74.99 \pm 8.33 \mathrm{a}$ & $96.43 \pm 3.57 \mathrm{a}$ & HS \\
\hline Euclide & $45 \pm 17.08 \mathrm{abc}$ & $87.5 \pm 7.5 \mathrm{a}$ & $160.62 \pm 30.08 \mathrm{ab}$ & $240 \pm 6.12 \mathrm{abc}$ & $87.5 \pm 12.5 \mathrm{a}$ & $97.5 \pm 2.5 \mathrm{a}$ & HS \\
\hline Agbotrui & $70 \pm 11.55 \mathrm{abcd}$ & $90 \pm 7.07 \mathrm{a}$ & $92.5 \pm 31.46 \mathrm{acd}$ & $213.75 \pm 22.49 \mathrm{abcd}$ & $95 \pm 5 \mathrm{a}$ & $95 \pm 5 \mathrm{a}$ & HS \\
\hline Adja & $62.5 \pm 14.93 \mathrm{abcd}$ & $97.5 \pm 2.5 \mathrm{a}$ & $128.75 \pm 36.82 \mathrm{abc}$ & $273.75 \pm 18.41 b c$ & $85 \pm 8.66 \mathrm{a}$ & $97.5 \pm 2.5 \mathrm{a}$ & HS \\
\hline Tropimech & $96.43 \pm 3.57 \mathrm{~cd}$ & $92.5 \pm 2.5 \mathrm{a}$ & $220 \pm 34.92 \mathrm{ab}$ & $213.75 \pm 15.86 \mathrm{abcd}$ & $100 \pm 0 \mathrm{a}$ & $97.5 \pm 2.5 \mathrm{a}$ & HS \\
\hline Hawai 7997 & $0 \pm 0 \mathrm{e}$ & $0 \pm 0 \mathrm{c}$ & $0 \pm 0 \mathrm{~d}$ & $0 \pm 0 \mathrm{f}$ & $100 \pm 0 \mathrm{a}$ & $87.5 \pm 7.5 \mathrm{a}$ & HR \\
\hline Prob & 0.0000 & 0.0000 & 0.0000 & 0.0000 & 0.1849 & 0.0398 & \\
\hline
\end{tabular}

In the same column, the means followed by the same letters are not significantly different according to the Student-Newmann-Keuls test with $\mathrm{P}=0.05$. $\mathrm{E}=$ Experimentation. Values after the \pm sign represent standard error.

Cobra 26 was moderately resistant, the Buffalo was susceptible and the Kêkêfô, Tropimèche, Petomech, Topaz, Jaguar, Prado, Tounvi, Akikonkouin, Anaya, Agbotrui, Cobra 34, Kiara, Adjaa, Savana, Euclid, Ninja and Sumo varieties were highly susceptible.

\subsection{Determination of the Bacterial Concentration in the Soil of the Experimental Site in Station}

The mean concentration of bacteria in the soil of experimental site varied among blocks. It was on average $5.5 \times 10^{3}, 5.4 \times 10^{3}, 3.1 \times 10^{3}$ and $1.8 \times 10^{3} \mathrm{CFU} \cdot \mathrm{g}^{-1}$ of soil for blocks 4, 3, 2 and 1, respectively. 


\subsection{Behavior of Tomato Varieties under Ralstonia solanacearum Pressure on Station}

In the on-station experiment under screen house, no significant difference was obtained for the IBW $(\mathrm{P}=0.1500)$. In the field experiment, the IBW showed significantly different among varieties $(P=0.000)$. The varieties PADMA, Hawaii 7997, Cobra 26 and Cobra 34 had the lowest IBW varying between $0 \%$ and $18.75 \%$. On the other hand, the highest IBW were recorded for the Kêkêfô, Tropimèche, Petomech, Topaze, Jaguar, Prado, Tounvi, Akikonkouin, Anaya, Agbotrui, Kiara, Adjaa, Buffalo, Savana, Euclide, Ninja and Sumo varieties, varying between $39.06 \%$ and $81.24 \%$.

For the field experiment, the BCI varied significantly among varieties, regardless of the experimental period $(\mathrm{P}<0.05)$. However, all the varieties tested were colonized. But, the BCI was low for the PADMA varieties, Hawaii 7997 varieties followed by the Cobra 26 variety (Table 3 ).

Table 3. Incidence of bacterial wilt, bacterial colonization index and area under the bacterial wilt incidence progress curve of 21 tomato varieties evaluated in the field experiment.

\begin{tabular}{|c|c|c|c|c|c|c|c|}
\hline \multirow{2}{*}{ Varieties } & \multicolumn{2}{|c|}{ IBW } & \multicolumn{2}{|c|}{ AUIbwPC } & \multicolumn{2}{|c|}{ BCI } & \multirow{2}{*}{ Reaction } \\
\hline & E1 & E2 & E1 & E2 & E1 & E2 & \\
\hline Kêkêfô & $51.56 \pm 21.85 \mathrm{a}$ & $76.34 \pm 6.48 \mathrm{a}$ & $133.59 \pm 67.68 \mathrm{abcd}$ & $47.10 \pm 4.01 \mathrm{abcd}$ & $60.94 \pm 17.75 \mathrm{ab}$ & $93.08 \pm 5.06 \mathrm{a}$ & HS \\
\hline Akikonkouin & $48.43 \pm 10.33 \mathrm{a}$ & $81.25 \pm 4.42 \mathrm{a}$ & $86.72 \pm 24.08 \mathrm{abcd}$ & $95.31 \pm 16.56 \mathrm{a}$ & $54.69 \pm 8.22 \mathrm{ab}$ & $89.06 \pm 3.93 \mathrm{a}$ & HS \\
\hline PADMA & $0 \pm 0 \mathrm{a}$ & $0 \pm 0 \mathrm{c}$ & $0 \pm 0 \mathrm{~d}$ & $0 \pm 0 \mathrm{~d}$ & $3.33 \pm 1.92 \mathrm{a}$ & $12.91 \pm 6.10 \mathrm{c}$ & $\mathrm{HR}$ \\
\hline Buffalo & $12.5 \pm 8.84 \mathrm{a}$ & $60.94 \pm 6.93 \mathrm{a}$ & $76.56 \pm 26.04 \mathrm{abcd}$ & $30.47 \pm 3.46 \mathrm{abcd}$ & $32.5 \pm 17.65 \mathrm{ab}$ & $87.5 \pm 13.74 \mathrm{a}$ & S \\
\hline Petomech & $26.56 \pm 10.64 \mathrm{a}$ & $51.80 \pm 7.84 \mathrm{ab}$ & $58.59 \pm 26.47 \mathrm{bcd}$ & $39.36 \pm 9.08 \mathrm{abcd}$ & $26.56 \pm 10.64 \mathrm{ab}$ & $88.82 \pm 5.07 \mathrm{a}$ & $S$ \\
\hline Savana & $32.81 \pm 11.80 \mathrm{a}$ & $67.19 \pm 4.69 \mathrm{a}$ & $63.28 \pm 21.44 \mathrm{bcd}$ & $67.97 \pm 11.15 \mathrm{abc}$ & $37.5 \pm 11.69 \mathrm{ab}$ & $85.94 \pm 2.99 \mathrm{a}$ & $S$ \\
\hline Ninja & $12.5 \pm 12.5 \mathrm{a}$ & $39.06 \pm 12.07 \mathrm{ab}$ & $12.5 \pm 12.5 \mathrm{~d}$ & $19.53 \pm 6.03 \mathrm{bcd}$ & $12.5 \pm 12.5 \mathrm{ab}$ & $76.56 \pm 17.38 \mathrm{ab}$ & S \\
\hline Topaze & $29.17 \pm 19.21 \mathrm{a}$ & $61.77 \pm 7.46 \mathrm{a}$ & $56.55 \pm 30.40 \mathrm{bcd}$ & $48.54 \pm 7.81 \mathrm{abcd}$ & $36.90 \pm 21.04 \mathrm{ab}$ & $82.52 \pm 12.88 \mathrm{a}$ & $S$ \\
\hline Jaguar & $34.37 \pm 8.27 \mathrm{a}$ & $76.56 \pm 4.69 \mathrm{a}$ & $59.37 \pm 21.31 \mathrm{bcd}$ & $66.41 \pm 13.76 \mathrm{abcd}$ & $42.19 \pm 10.33 \mathrm{ab}$ & $87.5 \pm 4.42 \mathrm{a}$ & $S$ \\
\hline Sumo & $4.28 \pm 2.54 \mathrm{a}$ & $50 \pm 16.73 \mathrm{ab}$ & $4.46 \pm 4.46 \mathrm{~d}$ & $39.06 \pm 7.05 \mathrm{abcd}$ & $6.78 \pm 2.36 \mathrm{a}$ & $92.19 \pm 2.99 \mathrm{a}$ & S \\
\hline Prado & $48.44 \pm 17.75 \mathrm{a}$ & $59.37 \pm 7.86 \mathrm{a}$ & $92.97 \pm 40.83 \mathrm{abcd}$ & $45.31 \pm 10.00 \mathrm{abcd}$ & $48.44 \pm 17.75 \mathrm{ab}$ & $93.75 \pm 3.60 \mathrm{a}$ & S \\
\hline Tounvi & $50 \pm 16.73 \mathrm{a}$ & $69.87 \pm 12.40 \mathrm{a}$ & $114.06 \pm 41.90 \mathrm{abcd}$ & $87.05 \pm 37.92 \mathrm{a}$ & $81.25 \pm 12.75 b$ & $87.31 \pm 7.65 \mathrm{a}$ & $S$ \\
\hline Cobra26 & $7.67 \pm 4.58 \mathrm{a}$ & $18.75 \pm 7.65 \mathrm{bcd}$ & $15.91 \pm 9.37 \mathrm{bc}$ & $9.37 \pm 3.83 b c$ & $7.67 \pm 4.58 \mathrm{a}$ & $43.75 \pm 8.84 \mathrm{~b}$ & MR \\
\hline Anaya & $15.62 \pm 15.62 \mathrm{a}$ & $57.51 \pm 3.44 \mathrm{a}$ & $162.5 \pm 29.09 \mathrm{ab}$ & $57.05 \pm 12.62 \mathrm{abcd}$ & $21.87 \pm 21.88 \mathrm{ab}$ & $75.58 \pm 2.51 \mathrm{ab}$ & $S$ \\
\hline Cobra34 & $6.25 \pm 4.42 \mathrm{a}$ & $14.06 \pm 4.69 \mathrm{~cd}$ & $10.94 \pm 8.12 \mathrm{~d}$ & $10.16 \pm 4.49 \mathrm{bc}$ & $7.81 \pm 5.92 \mathrm{a}$ & $59.37 \pm 5.41 \mathrm{ab}$ & MR \\
\hline Kiara & $19.93 \pm 7.70 \mathrm{a}$ & $68.75 \pm 7.12 \mathrm{a}$ & $29.17 \pm 9.98 b c$ & $77.08 \pm 19.65 \mathrm{ab}$ & $30.76 \pm 7.18 \mathrm{ab}$ & $85.42 \pm 5.24 \mathrm{a}$ & S \\
\hline Euclide & $15.62 \pm 7.86 \mathrm{a}$ & $39.52 \pm 12.78 \mathrm{ab}$ & $40.28 \pm 23.17 \mathrm{bcd}$ & $31.78 \pm 9.65 \mathrm{abcd}$ & $15.62 \pm 7.86 \mathrm{ab}$ & $66.31 \pm 14.03 \mathrm{ab}$ & $S$ \\
\hline Agbotrui & $31.35 \pm 18.99 a$ & $62.5 \pm 13.26 \mathrm{a}$ & $129.16 \pm 18.87 \mathrm{abcd}$ & $40.62 \pm 9.63 \mathrm{abcd}$ & $34.69 \pm 22.25 \mathrm{ab}$ & $90.62 \pm 5.41 \mathrm{a}$ & $S$ \\
\hline Adja & $37.5 \pm 12.5 \mathrm{a}$ & $66.87 \pm 6.72 \mathrm{a}$ & $148.44 \pm 26.32 \mathrm{abc}$ & $62.39 \pm 11.60 \mathrm{abcd}$ & $59.37 \pm 9.38 \mathrm{ab}$ & $85.94 \pm 10.33 a$ & S \\
\hline Tropimech & $25 \pm 25 \mathrm{a}$ & $75 \pm 8.46 \mathrm{a}$ & $190 \pm 21.60 \mathrm{a}$ & $62.5 \pm 5.56 \mathrm{abcd}$ & $25 \pm 25 \mathrm{ab}$ & $89.06 \pm 7.38 \mathrm{a}$ & HS \\
\hline Hawaii 7997 & $0 \pm 0 \mathrm{a}$ & $0 \pm 0 \mathrm{c}$ & $0 \pm 0 \mathrm{~d}$ & $0 \pm 0 \mathrm{~d}$ & $46.87 \pm 11.83 \mathrm{ab}$ & $12.5 \pm 7.65 \mathrm{c}$ & $\mathrm{HR}$ \\
\hline Prob & 0.1500 & 0,0000 & 0.0000 & 0,0000 & 0.0096 & 0,0000 & \\
\hline
\end{tabular}

In the same column, the means followed by the same letters are not significantly different according to the Student-Newmann-Keuls test with $\mathrm{P}=0.05$. $\mathrm{E}=$ Experiment. Values after the \pm sign represent standard error. 
The AUIbwPC showed a similar trend to the IBW obtained. The lowest values were recorded for the PADMA, Hawaii 7997, Cobra 26 and Cobra 34 varieties and varied between 0 and 10.94 (experiment 1 ) and between 0 and 9.37 (experiment 2). The other varieties showed a significantly higher AUIbwPC ranging from 12.5 to 190 for experiment 1 and from 10.16 to 95.31 for experiment 2 .

\section{Discussion}

Bacterial wilt of Solanaceae is one of the major constraints to tomato production in Benin [6]. In the current study, the behaviour of 21 hybrid and local tomato varieties was evaluated after artificial inoculation in the screen house and on a field naturally infested by $R$. solanacearum. The results showed that under both experimental conditions, the response of tomato plants to $R$. solanacearum disease varied from one variety to another. Thus, the 21 varieties tested included Tounvi which is a known local susceptible variety, Hawaii 7997 and PADMA which are known resistant ones, Cobra 26 as moderately resistant, and the 17 other following varieties as susceptible to bacterial wilt: the local Kêkêfô, Agbotrui, Adjaa, Akikonkouin and the hybrids Sumo, Prado, Ninja, Jaguar, Anaya, Topaze, Cobra 26, Cobra 34, Euclide, Savana, Kiara, Buffalo, Petomech, Tropimech. Among the five tested local tomato varieties, only Tounvi was previously reported as a susceptible variety to bacterial wilt [6] [16]. The behavior of the other local varieties Kêkêfô, Agbotrui, Adjaa and Akikonkouin to bacterial wilt was not reported before. The current study reports, for the first time, the susceptibility of these local varieties to bacterial wilt. It is also the first time the hybrid varieties Sumo, Prado, Ninja, Jaguar, Anaya, Topaze, Cobra 34, Euclid, Savana, Kiara, Buffalo, Petomech and Tropimech are reported as susceptible varieties to bacterial wilt caused by $R$. solanacearum. Moreover, these results showed that varietal susceptibility to bacterial wilt did not depend on the status of the variety, whether local or hybrid varieties. Ganiyu et al. [19] and Aslam et al. [10] also reported the susceptibility of hybrid and open pollinated tomato varieties to bacterial wilt.

During the screen house and field experiments, the variety Cobra 26 showed resistance to bacterial wilt recording the lowest IBW. Drame et al. [26] also identified the tomato variety Cobra 26 as resistant to bacterial wilt over two consecutive years in the field. Cobra 26 variety could be promoted and used across the sub-regions in infested areas by $R$. solanacearum phylotype 1 strains. It can also be used in the resistance gene identification studies programme.

The Hawaii 7997 and PADMA varieties recorded 0\% wilted plants in the screen house and in the field. The resistance Hawaii 7997 and PADAM varieties to bacterial wilt has been reported in previous studies [16] [27]. According to reports from Grimault et al. [28]; Monma et al. [29] and Oliveira et al. [30], this resistance trait might be due to single dominant or recessive genes.

The variety Cobra 34 showed an unstable state of resistance to bacterial wilt. With the field results, the variety Cobra 34 appeared to be resistant. The bacterial pressure induced by artificial inoculation demonstrated the real state of sus- 
ceptibility of this variety. This result showed that artificial inoculation of pathogens to crop assures a better breeding study for resistance. This result corroborates those of Sikirou and Wydra [31] who reported that the number of cowpea varieties previously selected as resistant in the field was reduced when artificially inoculated. On the other hand, the varieties Kêkêfô, Akikonkouin, Agbotrui, Adjaa, Sumo, Prado, Ninja, Jaguar, Anaya, Topaz, Euclid, Savana, Kiara, Buffalo, Petomech and Tropimech tested in the same conditions wilted under artificial and naturally infection conditions. This result might show that the bacterial concentration of about $10^{3} \mathrm{CFU} \cdot \mathrm{ml}^{-1}$ is enough to induce bacterial wilt in the field. Thus, the tomato variety Cobra 34 might not be considered as resistant since it wilted the most after artificial inoculation as compared to natural field inoculation.

In addition, the current finding showed that all the tested varieties, were colonized by $R$. solanacearum, regardless of their susceptibility or resistance level. These results might reveal that resistance of a variety to $R$. solanacearum does not prevent its penetration into the variety as indicated by Sang et al. [32]. These authors explained that varietal resistance does not depend on whether or not the plant is infested, but on its ability to prevent the pathogen from obstructing the sap-conducting vessels.

Our finding also showed that the IBW was low during the experiment 1 of screen house which was conducted during rainy season and high during the experiments 2 conducted when weather was dry. This weather condition during the experiment 2 seems to increase disease expression up to $76.19 \%$ and $90.47 \%$ of the tested varieties in the screen house and in the field, respectively. The increase in the temperatures by $2.9^{\circ} \mathrm{C}$ and $4.4^{\circ} \mathrm{C}$ in screen house and in the field respectively, might favour the disease development leading to the observed results. These might suggest that bacterial wilt is more damaging in hot conditions and may be a key factor favouring $R$. solanacearum virulence. These results are similar to those found by Caruso et al. [33] who concluded that $R$. solanacearum loses its virulence at low temperatures during their study on population variation of $R$. solanacearum biovar 2 in Spanish rivers at different seasons. In addition, the studies by van Overbeek et al. [34] on the storage temperatures of $R$. solanacearum biovar 2 strains demonstrated that low temperature induces virulence loss for $R$. solanacearum. Our results are also in line with those of Singh et al. [35] who evaluating the effect of temperature, cultivar and induced root wounding on virulence of $R$. solanacearum in greenhouse tomato crops, showed no wilt symptoms at $20^{\circ} \mathrm{C}$ or lower. In addition, Bittner et al. [36], breeding tobacco varieties resistant against $R$. solanacearum, reported the highest incidences when temperatures were between $30^{\circ} \mathrm{C}$ and $35^{\circ} \mathrm{C}$ and no symptoms at temperatures less than or equal to $15^{\circ} \mathrm{C}$. Oussou et al. [16] also reported a high wilt rate of Solanum macrocarpum artificially inoculated with $R$. solanacearum during the dry period compared to the wet period.

The susceptibility behaviour of local and hybrid tomato varieties cultivated in Benin could result in a rapid expansion of the bacterial wilt with consequent re- 
duction of tomato yield in the contaminated areas where access to seeds of resistant varieties is difficult. The current study identified Cobra 26 as moderately resistant variety which is good alternative to control $R$. solanacearum wilt disease in the field. Efforts should continue to identify more resistant or moderately resistant varieties and evaluate other open-pollinated varieties to identify the resistant ones to $R$. solanacearum.

\section{Conclusion}

The response of tomato varieties to $R$. solanacearum stress varies from one variety to another. Out of the 21 tomato tested varieties, Cobra 26 was the only variety identified to be moderately resistant to bacterial wilt. The variety Buffalo was susceptible while the Kêkêfô, Akikonkouin, Tounvi, Agbotrui, Petomech, Savana, Ninja, Topaze, Jaguar, Sumo, Prado, Anaya, Kiara, Euclid, Cobra 34, Adja and Tropimech varieties were highly susceptible. This is the first report revealing Cobra 26 as moderately resistant variety identified during the current study. Resistant and moderately resistant tomato varieties to bacterial wilt should, when identified, be recommended to farmers and used to improve the open-pollinated varieties preferred by rural farmers.

\section{Acknowledgements}

The authors thank the Vegetable Program (PCM) of INRAB for providing seeds and watering facilities and World Vegetable Center (WorldVeg) for providing seeds.

\section{Conflicts of Interest}

The authors declare no conflicts of interest regarding the publication of this paper.

\section{References}

[1] FAOSTAT (2021) Food and Agriculture Organization Corporate Statistical Database. http://www.fao.org/faostat/en/\#data/QC

[2] Assogba-Komlan, F., Anihouvi, P., Achogan-Dako, E., Sikirou, R., Boko, A., Adjé, C., Vodounhè, R.V. and Assa, A. (2007) Pratiques culturales et teneur en éléments antinutritionnels (nitrate et pesticides) du Solanum macrocarpum au sud-Bénin. African Journal of Food Agriculture and Development, 7, 1-21.

[3] James, B., Atcha-Ahowé, C., Godonou, I., Baimey, H., Goergen, G., Sikirou, R. and Toko, M. (2010) Integrated Pest Management in Vegetable Production. Guidelines for Extension Workers in West Africa. International Institute of Tropical Agriculture (IITA), Ibadan.

[4] Grubben, G., Nono-Womdim, R., Everaarts, A., Fondio, L., Nugteren, J.A. and Corrado, M. (2014) Vegetables to Combat the Hidden Hunger in Africa. Chronica Horticultae, 54, 24-32.

[5] Yolou, F.I., Yabi, I., Kombieni, F., Tovihoudji, P.G., Yabi, J.A., Paraïso, A.A. and Afouda, F. (2015) Maraîchage en milieu urbain à Parakou au Nord-Bénin et sa rentabilité économique. International Journal of Innovation and Scientific Research, 
19, 290-302.

[6] Sikirou, R., Beed, F., Ezin, V., Gbehounou, G., Miller, S.A. and Wydra, K. (2009) First Report of Bacterial Wilt of Tomato (Solanum lycopersicum) Caused by Ralstonia solanacearum in Benin. Plant Disease, 93, 549.

https://doi.org/10.1094/PDIS-93-5-0549B

[7] Sikirou, R., Beed, F., Ezin, V., Hoteigni, J. and Miller, A.S. (2017) Distribution, Pathological and Biochemical Characterization of Ralstonia solanacearum in Benin. Annals of Agricultural Science, 62, 83-88. https://doi.org/10.1016/j.aoas.2017.05.003

[8] BoShou, L. (2005) A Broad Review and Perspective on Breeding for Resistance to Bacterial Wilt. In: Allen, C., Prior, P. and Hayward, A.C., Eds., Bacterial Wilt Disease and the Ralstonia solanacearum Species Complex, Saint Paul APS Press, Minnesota, 225-238.

[9] Balestra, G.M., Heydari, A., Ceccarelli, D., Ovidi, E. and Quattrucci, A. (2009) Antibacterial Effect of Allium sativum and Ficus carica Extracts on Tomato Bacterial Pathogens. Crop Protection, 28, 807-811.

https://doi.org/10.1016/j.cropro.2009.06.004

[10] Aslam, M.N., Mukhtar, T., Hussain, M.A. and Raheel, M. (2017) Assessment of Resistance to Bacterial Wilt Incited by Ralstonia solanacearum in Tomato Germplasm. Journal of Plant Diseases and Protection, 124, 585-590. https://doi.org/10.1007/s41348-017-0100-1

[11] Comes, S., Fanigliulo, A., Pacella, R. and Crescenzi, A. (2009) Severe Outbreak of Tomato Yellow Leaf Curl Sardinia Virus on Pepper in Southern Italy. Communications in Agricultural and Applied Biological Sciences, 74, 913-916.

https://doi.org/10.17660/ActaHortic.2009.808.30

[12] Rivard, C., O'connell, S., Peet, M., Welker, R. and Louws, F. (2012) Grafting Tomato to Manage Bacterial Wilt Caused by Ralstonia solanacearum in the Southeastern United States. Plant Disease, 96, 973-978. https://doi.org/10.1094/PDIS-12-10-0877

[13] Deberdt, P., Guyot, J., Coranson-Beaudu, R., Launay, J., Noreskal, M. and Riviere, P. (2014) Diversity of Ralstonia solanacearum in French Guiana Expands Knowledge of the Emerging Ecotype. Phytopathology, 104, 586-596.

https://doi.org/10.1094/PHYTO-09-13-0264-R

[14] Kakuhenzire, R., Lemaga, B., Kashaija, I., Ortiz, O. and Mateeka, B. (2013) Effect of Crotalaria falcata in Crop Rotation and Fallowing on Potato Bacterial Wilt Incidence, Disease Severity and Latent Infection in Tubers and Field Soil. Biopesticides International, 9, 182-194.

[15] Ayana, G. and Fininsa, C. (2016) Effect of Crop Rotation on Tomato Bacterial Wilt (Ralstonia solanacearum) and Survival of the Pathogen in the Rhizospheres and Roots of Different Crops in Ethiopia, International Journal of Phytopathology, 5, 95-102. https://doi.org/10.33687/phytopath.005.03.1932

[16] Oussou, G.F.G.N., Sikirou, R., Afoha, S.A.P.E., Dossoumou, M.E.E.A., Boukari, S.A., Komlan, F.A. and Zocli, B. (2020) Resistance Assessment of Tomato (Solanum lycopersicum L.) and Gboma (Solanum macrocarpon L.) Cultivars against Bacterial Wilt Caused by Ralstonia solanacearum in Benin. Pakistan Journal of Phytopathology, 32, 241-249. https://doi.org/10.33866/phytopathol.030.02.0610

[17] Wang, J.-F., Olivier, J., Thoquet, P., Mangin, B., Sauviac, L. and Grimsley, N.H. (2000) Resistance of Tomato Line Hawaii7996 to Ralstonia solanacearum Pss4 in Taiwan Is Controlled Mainly by a Major Strain-Specific Locus. Molecular Plant-Microbe Interactions, 13, 6-13. https://doi.org/10.1094/MPMI.2000.13.1.6 
[18] Kim, S.G., Hur, O.-S., Ro, N.-Y., Ko, H.-C., Rhee, J.-H., Sung, J.S., Ryu, K.-Y., Lee, S.-Y. and Baek, H.J. (2016) Evaluation of Resistance to Ralstonia solanacearum in Tomato Genetic Resources at Seedling Stage. Plant Pathology Journal, 32, 58-64. https://doi.org/10.5423/PPJ.NT.06.2015.0121

[19] Ganiyu, S.A., Popoola, A.R., Enikuomehein, O.A., Badunde, J.G., Adedibu, O.B. and Gurama, A.U. (2017) Assessment of Resistance Status of Some Tomato Genotypes to Bacterial Wilt Disease and Evaluation of SNP Marker (LEOH19) for Selection of BW Resistant Gene. Nigerian Journal of Biotechnology, 34, 54-64.

https://doi.org/10.4314/njb.v34i1.8

[20] Laeshita, P. and Arwiyanto, T. (2017) Resistance Test of Several Tomato Varieties to Bacterial Wilt Diseases Caused by Ralstonia solanacearum. Journal Perlindungan Tanaman Indonesia, 21, 51-53.

[21] Aglinglo, A.L., Ahoudou, I., Legba, C.E., Francisco, R., Hotègni, F.V.N. and Achigan-Dako, G.E. (2018) Fiche technique synthétique pour la production de la Tomate (Lycopersicon esculentum Mill.). Laboratory of Genetics, Horticulture and Seed Science (GBioS), Université d'Abomey-Calavi (UAC), Abomey-Calavi.

[22] Wicker, E., Grasart, L., Coranson-Beaudu, R., Mian, D. and Prior, P. (2009) Epidemiological Evidence for the Emergence of a New Pathogenic Variant of Ralstonia solanacearum in Martinique (French West indies). Plant Pathology, 58, 853-861. https://doi.org/10.1111/j.1365-3059.2009.02098.x

[23] Engelbrecht, M.C. (1994) Modification of a Semi-Selective Medium for the Isolation and Quantification of Pseudomonas solanacearum. Australian Centre for International Agricultural Research Bacterial Wilt Newsletter, 10, 3-5.

[24] Mew, T.W. and Ho, W.C. (1977) Effect of Soil Temperature on Resistance of Tomato Cultivars to Bacterial Wilt. Phytopathology, 67, 909-911.

https://doi.org/10.1094/Phyto-67-909

[25] Jeger, M. and Viljanen-Rollinson, S. (2001) The Use of the Area under the Disease-Progress Curve (AUDPC) to Assess Quantitative Disease Resistance in Crop Cultivars. Theoretical and Applied Genetics, 102, 32-40. https://doi.org/10.1007/s001220051615

[26] Drame, B., Kane, P.D., Mbaye, A.A., Faye, A. and Noba, K. (2021) Etude de la sensibilité variétale de la tomate (Solanum lycopersicum L.) Au flétrissement bactérien du à Ralstonia solanacearum dans la vallée du fleuve Sénégal. International Journal of Advanced Research, 9, 1-11. https://doi.org/10.21474/IJAR01/12273

[27] Hanson, P.M., Licardo, O., Wang, J.-F. and Chen, J.-T. (1998) Diallel Analysis of Bacterial wilt Resistance in Tomato Derived from Different Sources. Plant Disease, 82, 74-78. https://doi.org/10.1094/PDIS.1998.82.1.74

[28] Grimault, V., Prior, P. and Anais, G. (1995) A Monogenic Dominant Resistance of Tomato to Bacterial Wilt in Hawaii 7996 Is Associated with Plant Colonization by Pseudomonas solanacearum. Journal of Phytopathology, 143, 349-352. https://doi.org/10.1111/j.1439-0434.1995.tb00274.x

[29] Monma, S., Sakata, Y. and Matsunaga, H. (1997) Inheritance and Selection Efficiency of Bacterial Wilt Resistance in Tomato. Jarq-Japan Agricultural Research Quarterly, 31, 195-204.

[30] Oliveira, W., Giordano, L. and Lopes, C. (1999) Inheritance of Resistance to Bacterial Wilt in Tomato. Fitopatologia Brasileira, 24, 49-53.

[31] Sikirou, R. and Wydra, K. (2003) Selection of Local and Improved Cowpea Genotypes Resistant to Bacterial Blight Caused by Xanthmonas axonopodis pv. vignicola. 
Annales des Sciences Agronomiques, 6, 49-60.

[32] Sang, G.K., On-Sook, H., Na-Young, R., Ho-Cheol, K., Ju-Hee, R., Jung, S.S., Kyoung-Yul, R., Sok-Young, L. and Hyung, J.B. (2016) Evaluation of Resistance to Ralstonia solanacearum in Tomato Genetic Resources at Seedling Stage. Plant Pathology Journal, 32, 58-64. https://doi.org/10.5423/PPJ.NT.06.2015.0121

[33] Caruso, P., Palomo, J.L., Bertolini, E., Alvarez, B.A., Lopez, M.M., Elena, G. and Biosca, E.G. (2005) Seasonal Variation of Ralstonia solanacearum Biovar 2 Populations in a Spanish River: Recovery of Stressed Cells at Low Temperatures. Applied and Environmental Microbiology, 71, 140-148.

https://doi.org/10.1128/AEM.71.1.140-148.2005

[34] van Overbeek, L.S., Bergervoet, J.H.W., Jacobs, F.H.H. and van Elsas, J.D. (2004) The Low-Temperature-Induced Viable-But Nonculturable State Affects the Virulence of Ralstonia solanacearum biovar 2. Phytopathology, 94, 463-469. https://doi.org/10.1094/PHYTO.2004.94.5.463

[35] Singh, D., Yadav, D.K., Sinha, S. and Choudhary, G. (2013) Effet of Temperature, Cultivars, Injury of Root and Inoculums Load of Ralstonia solanacearum to Cause Bacterial Wilt of Tomato. Archives of Phytopathology and Plant Protection, 47, 1574-1583. https://doi.org/10.1080/03235408.2013.851332

[36] Bittner, R.J., Arellano, C. and Mila, A.L. (2016) Effect of Temperature and Resistance of Tobacco Cultivars to the Progression of Bacterial Wilt, Caused by Ralstonia solanacearum. Plant Soil, 408, 299-310.

https://doi.org/10.1007/s11104-016-2938-6 